\title{
Phytochemical and pharmacological review on Stephania japonica
}

\author{
Apu Kumar Das, Shamim Molla, Musfiqur Rahman Sykat, Md. Ahad Ali, Md. Tanziul Haque, \\ Md. Lutfor Rahman, Imam Mohiuddin Babu, Md. Hamidul Islam and Muhammad Torequl Islam* \\ Department of Pharmacy, Bangabandhu Sheikh Mujibur Rahman Science and Technology, Bangladesh \\ *Corresponding author: Muhammad Torequl Islam, Department of Pharmacy, Life Science Faculty, Bangabandhu Sheikh Mujibur \\ Rahman Science and Technology, Gopalganj-8100, Bangladesh
}

\section{ARTICLE INFO}

Received: 崫 January 25, 2019

Published: 幽 February 06, 2019

Citation: Apu Kumar Das, Shamim Molla, Musfiqur Rahman Sykat, Md. Ahad Ali, Md. Tanziul Haque, Md. Lutfor Rahman, Imam Mohiuddin Babu, Md. Hamidul Islam, Muhammad Torequl Islam. Phytochemical and pharmacological review on Stephania japonica. Biomed J Sci \& Tech Res 14(1)-2019. BJSTR. MS.ID.002500.

\begin{abstract}
This paper reviews phytochemical and pharmacological profiles of Stephania japonica from the databases PubMed, Science Direct and Google Scholar up to December 2018. S. japonica is a common plant, widely distributed in all over Bangladesh. Traditionally, this plant is considered as one of the important medicinal plants in the treatment of a variety of ailments, including inflammation, pain, rheumatism, cancer, bone fracture and fever. Findings suggest that $S$. japonica is rich in important phytochemicals, including alkaloids, steroids, saponins and fats. It is evident to possess anti-inflammatory, antioxidant, antidiarrheal, antimicrobial, insecticidal, anti-nociceptive, neuro-protective, analgesic and anti-hyperglycaemic activities. In conclusion, S. japonica may be one of the best sources of plant-based active constituents.
\end{abstract}

Keywords: Stephania Japonica; Phytochemicals; Pharmacological Activities

\section{Introduction}

Plants have been used in traditional medicine since ancient time with a reputation as efficacious remedies regardless of insufficient scientific evidence to substantiate their efficacy. The exploration of the chemical properties of the plants throughout the age was accomplished principally through careful observation, trial and error and the accidental discovery. In this process, the human race, over the centuries, has created a vast heritage of knowledge and experience on medicinal plants in different cultures and civilizations. Most of such indigenous knowledge handed down, through the ages, by oral tradition. The major portion of the present-day knowledge of the medicinal properties of the plants is thus the sum total of these observations and experience [1]. The plant Stephania japonica Linn. belongs to the family Menisperaceae, a slender wiry climber or twining shrub [2], is widely used in the traditional medicine of Bangladesh in the treatment of a wide range of diseases and disorders, including inflammation, cancer, asthma, fever, sleep disturbance, edema, and bone fracture [3,4]. Especially its leaves, are extensively used to treat different kinds of painful conditions, more specifically, the crushed leaves for body pain $[4,5]$ and warmed leaves for rheumatism [6]. In 1982, Matsui have isolated two hasubanan type alkaloid oxostephamiersine $(284 \mathrm{mg}$ ) and 16- oxoprometaphanine (238.5 $\mathrm{mg}$ ) and one bisbenzylisoquinoline type alkaloid stebisimine (192.5 mg) from the methanolic extract $S$. japonica leaves. This review aimed at sketching a current scenario on the phytochemical and pharmacological activities of $S$. japonica on the basis of scientific reports found in PubMed, Science Direct and Google Scholar databases up to December 2018.

\section{Findings}

\section{Plant Morphology}

S. japonica is a slender wiry climber. Leaves peltate, thinly papyraceous, glabrous on both the surfaces, broadly triangular, ovate-acuminate, 3-12 cm long, apex acutely acuminate or obtuse, base rounded, margins entire. Inflorescence axillary, compound, umbelliform cymes, usually singleper axil, 3-6 cm long. Flowers small, male flower greenish-white or yellowish. Drupes light yellow to orange red, obovate, glabrous [7]. 


\section{Taxonomy}

Kingdom: Plantae

Order: Ranunculales

Family: Menispermaceae

Genus: Stephania

Species: S. japonica

\section{Synonyms}

S. hernandifolia Walp., Menispermum japonicum Thunb.

Bengali/Vernacular Name: Akanadi, Nimuka, Maknadi.

Tribal Name: Tung Nah Way, ThayaNuya (Marma).

English Name: Tape-vine [7].

\section{Traditional Uses}

Leaves and roots are bitter and astringent; used in fever, diarrhoea, urinary diseases and dyspepsia. Leaves are mounted on the abscess and kept for bursting. Leaves are macerated in a glass of water and are taken after mixing with molasses to cure urethritis. Leaves are also given for gastritis in Khagrachari. On the other hand, tooth paste is taken for vertigo and dysentery; root tuber mixed with root juice of Flemingia stricta (Family: Leguminosae) is taken for asthma; the root paste is warmed and rubbed in hydrocele. The ethanolic leaf extract of the plant is evident to have broad spectrum anti-bacterial and anti-fungal activities [7,8].

\section{Phytochemical Composition}

Roots, tubers and leaves of S. japonica contain alkaloids, steroids and fats. Stems contain bis-benzylisoquinoline alkaloids, stephasubine and 3',4'-dihydro-stephasubine, saponins, steroids and fats. Roots contain the alkaloids, fangchinoline, dltetrandrine, d-tetrandrine and disochondrodendrine. Aerial parts of the plant contain aknadinine, epistephanine, hernandifoline and magnoflorine. Roots and tubers contain alkaloids - aknadinine, aknadine and aknadicine. A new alkaloid-3-0-di-methylhernandifoline was also isolated from the plant [7]. The plant is also evident to possess tannins, glycosides, flavonoids and [9].

\section{Pharmacological Activities}

\section{Anti-Inflammatory Activity}

The plant extract (methanol) has been found to show significant anti-inflammatory effect on egg albumin method [10]. Ahmed et al. [11] also suggested an anti-inflammatory effect of the plant.

\section{Antioxidant Activity}

The crude extract of the plant is evident to scavenge 2,2-diphenyl-1-picrylhydrazyl (DPPH) free radical at 20-200 $\mu \mathrm{g} / \mathrm{ml}$ $[11,12]$. The IC50 values were calculated as $33.57 \mu \mathrm{g} / \mathrm{ml}[12]$.

\section{Anti-Diarrheal Activity}

S. japonica ethanol extract at dosage level $0.5,1$ and $2 \mathrm{~g} / \mathrm{kg}$ decreased the gastrointestinal motility and number of feces in rats ( $n=5)$ (Chatterjee, 1993).

\section{Anti-Microbial and Cytotoxic Effect}

Ethyl acetate soluble fraction of the $S$. japonica extract was found to act against Salmonella typhi, Escherichia coli and Bacillus cereus. The zones of inhibition produced by the crude methanolic extract, n-hexane, chloroform and ethyl acetate soluble fractions were found to be $12.80-16.55 \mathrm{~mm}, 12.60 \mathrm{~mm}, 5-14.30 \mathrm{~mm}$ and 10 $20.25 \mathrm{~mm}$, respectively, at a concentration of $30 \mathrm{~g} /$ disc (Rahman). Chloroform, n-hexane and ethyl acetate soluble fractions of methanolic extract of $S$. japonica were also found to produce a concentration-dependent cytotoxic effect in brine shrimps. The chloroform and ethyl acetate soluble fractions of methanolic extract of $S$. japonica showed cytotoxicity (with $\mathrm{LC}_{50} 66.488$ and 45.662 $\mathrm{mg} / \mathrm{ml}$, respectively) (Rahman).

\section{Insecticidal Activity}

1, 5 and $10 \mathrm{mg}$ solutions of plant extract (acetone fraction) exhibited the insecticidal effect [13]. The plant is also evident to act against Callosobruchus chinensis where at dose $5 \mathrm{mg}$, it achieved $50 \%$ death of test insect [14].

\section{Anti-Nociceptive Activity}

$S$. japonica is evident to show analgesic effect in mice [15]. The methanolic extract of the plant at 50,100, and $200 \mathrm{mg} / \mathrm{kg}$ was evident to show an anti-nociceptive effect in mice [9].

\section{Neuro-Protective Activity}

In a recent study, methanolic extract of the herb showed a neuroprotective effect, possibly by reducing oxidative stress, neuroinflammation and inhibiting cholinesterase activity [10].

\section{Anti-Hyperglycemic Effect}

The methanolic extract of the plant at 250 and $500 \mathrm{mg} / \mathrm{kg}$ is evident to exert an anti-hyperglycemic effect in experimental rats [16]. S. japonica mediated anti-hyperglycemic effect was also seen by Ueda et al. [17], Gregersen et al. [18] and Hossain et al. [19].

\section{Discussion}

There is a relation between oxidative stress and inflammation [20]. Phenolic natural compounds such as flavonoids possess antioxidant and anti-inflammatory activity [21]. It is well established that the first phase of formalin test reflects neurogenic pain and the late phase corresponds to inflammatory pain responses [22]. Thus, the antioxidant and anti-inflammatory responses are the best sign of probable potent $S$. japonica-based constituents for the traditional usages, especially in inflammation and pain. Medicinal plant extracts offer considerable potential for the development 
of new agents effective against pathogents that are currently difficult to treat [23]. Noxious stimuli or infection is also related to inflammation cells [20]. S. japonica mediated antimicrobial effect is also evident in scientific report (Rahman). Recent evidence indicates that cytokines (and chemokines), as well as their receptors, are involved in the pathophysiology of many inflammatory diseases including sepsis, rheumatoid arthritis atheroscloresis and asthma. These pathological states seem to be linked with an imbalance of cytokine network and to the excessive recruitment of leukocytes to the inflammatory sites [24,25] (Young).

Because of this, the cytokine system constitutes a very interesting and promising target for the development of clinically relevant anti-inflammatory drugs. Carrageenan induced paw edema in rats is thought to be biphasic [26]. In the second phase bradykinin, protease, prostaglandin, and lysosome are released [27]. Evidence supports that various plant-derived compounds with anti-inflammatory properties exert their effects through the modulation of cytokine system [28]. For instance, flavonoids, a class of compounds widely distributed throughout the plant kingdom possess interesting anti-inflammatory action [29]. So, resulting anti-inflammatory and antioxidant effect could be assumed either as the protective effect against oxidative stress or inhibition of enzymes of prostaglandin pathway or other enzymatic path ways of inflammatory process. Further, anti-inflammatory, anti-microbial and anti-diarrheal effects of S. japonica may be linked with each other. On the other hand, anti-hyperglycaemic and cytotoxic effects of the herb indicate potential sources of anti-diabetic and anti-cancer substances in it. Generally, antioxidant and antiinflammatory effects are protective in nature [10]. Therefore, the neuroprotective capacity of the plant may be due to its antioxidant effects in different test systems [30-33].

\section{Conclusion}

S. japonica contains a number of important phytoconstituents and possesses prominent biological activities. More studies are necessary as $S$. japonica may be one of the best sources of phytomedicines.

\section{Conflict of interest}

None declared.

\section{References}

1. Ghani A (2003) Medicinal Plants of Bangladesh with Chemica Constituents and Uses, ( $2^{\text {nd }}$ Edi.). Asiatic Society of Bangladesh: Dhaka pp. 1-16.

2. Senthamarai R, Ismail AM, Kiurbha TSV, Balasubramanian P (2012) Pharmacognostical and phytochemical studies on leaves of Stephania japonica Linn. J Chem Pharm Res 4(3): 1457-1464.

3. Kirtikar KR, Basu BD (1981) Indian Medicinal Plants. International Book Distributors, India.

4. Jahan R, Khatun MA, Nahar N, Jahan FI, Chowdhury AR, et al. (2010) Use of Menispermaceae family plants in folkmedicine of Bangladesh. Adv Nat Appl Sci 4(1): 1-9.
5. Seraj S, Jahan FI, Chowdhury AR, Monjur-EKhuda M, Khan MSH, et al. (2013) Tribalformulations for treatment of pain: a study of the bede community traditional medicinalpractitioners of porabari village in dhaka district, bangladesh. Afric J Tradit Complement Altern Med 10(1): 26-34.

6. Rahman MA, Uddin SB, Wilcock CC (2007) Medicinal plants used by Chakma tribe in Hill Tracts districts of Bangladesh. Indian J Tradit Know 6(3): 508-517.

7. Anil B, Bhadauria NS, Jakhmola SS, Bhatnagar A (2001) Varietal preference of pulse beetle, Callosobruchus maculatus in cowpea. Indian J Entomol 63: 233-236.

8. Varalakshmi KN, Sangeetha CG, Samee US, Irum G, Lakshmi H, et al. (2011) In Vitro Safety Assessment of the Effect of Five Medicinal Plants on Callosobruchus maculatus (Fab.) 15: 283-284.

9. Moniruzzaman M, Hossain MS, Bhattacharjee PS (2016) Evaluation of antinociceptive activity of methanolic extract ofleaves of Stephania japonica Linn. J Ethnopharmacol 186: 205-208.

10. Islam MT, Khatun MJ (2017) Antioxidant mediated neuroprotective and GABAergic calming effect of Stephania japonica. Int J Med 5(2): 190-194.

11. Ahmed NU, Akter R, Satter MA, Khan MS, Islam F, et al. (2011) AntiInflammatory, Antioxidant and Anti-Diarrheal Effects of Ethanol Extract of Stephania japonica. Bangladesh J Sci Ind Res 46(4): 437-442.

12. Braca AT, Nunziatina DB, Lorenzo Di, Pizza C, Politi M, Morelli I (2001) Antioxidant principles from Bauhinia terapotensis. J Nat Prod 64: 892895 .

13. Talukder FA, Howse PE (1993) Deterrent and insecticidal effects of extract of pithraj, Aphanamixis polystachya against Tribolium castaneum in storage. J Chem Ecol 19(11): 2463-2471.

14. Ahmed F (2016) Insecticidal effects of Stephania japonica L. on pulse beetle (Callosobruchus chinensis L.), rice weevil (Sitophyllus oryzae L.) and Mosquito larvae.

15. Ahmed F, Selim MST, Das AK, Choudhuri MSK (2004) Anti-inflammatory and antinociceptive activities of Lippia nodiflora Linn. Pharmazie 59(4): 329-330.

16. Gosh S, Suryawanshi SA (2001) Effects of Vincarosea extracts in the treatment of alloxan diabetes in male albino rats. Indian J Exp Biol 39(8): 748-759.

17. Ueda M, Weffort RMM, Zubioli A, Bersani ACA, Bazotte RB, et al. (1983) Efeito do extratoaquoso da Stevia rebaudiana (Bert) Bertonisobre o teste de tolerância à glicose em ratos normais adultos. Rev Unimar 5: 111-115.

18. Gregersen S, Jeppesen PB, Holst JJ, Hermansen K (2004) Antihyperglycemic effects of stevioside in type 2 diabetic subjects. Metabolism 53(1): 73-76.

19. Hossain MS, Khan MRI, Anisuzzaman ASM, Ahmed M, Amran MS, et al. (2010) Antidiabetic and glycogenesis effects of different fractions of ethanolic extract of leaves of $M$. indica (Linn.) in normal and alloxan induced diabetic rats. J Med Sci 10(4): 80-86.

20. Sorci G, Faivre B (2009) Inflammation and oxidative stress in vertebrate host-parasite systems. Phil Trans R Soc B 364(1513): 71-83.

21. Sacca R, Cuff CA, Ruddle NH (1997) Mediators of inflammation. Curr Opin Immunol 9(6): 851-857.

22. Hunskaar S, Hole K (1987) The formalin test in mice: dissociation between inflammatory and non-inflammatory pain. Pain 30(1): 103114.

23. Machado TB, Leal ICR, Amaral ACF, Kokis V, de Silva MG, et al. (2005) Brazilian phytopharmaceuticals evaluation against hospital bacteria. Phytother Res 19(6): 519-525.

24. Feldmann M, Brennan FM, Maini R (1998) Cytokines in autoimmune disorders. Int Rev Immunol 17: 217-228. 
25. Haddad JJ (2002) Cytokines and related receptor-mediated signaling pathways. Biochem Biophys Res Commun 297(4): 700-713.

26. Vinegar R, Schreiber W, Hugo R (1969) Biphasic development of carrageenan edema in rats. J Pharmacol Exp Ther 166(1): 96-103.

27. Crunkhorn P, Meacock SC (1971) Mediators of the inflammation induced in the rat paw by carrageenan. Br J Pharmacol 42(3): 392-402.

28. Habtemariam S (2000) Natural inhibitor of tumor necrosis factor-alpha production, secretion and function. Planta Med 66(4): 303-313.

29. Gerritsen ME, Carley WW, Ranges GE, Shen CP, Phan SA, et al. (1995) Flavonoids inhibit cytokine-induced endothelial cell adhesion protein gene expression. Am J Pathol 147(2): 278-292.

\section{ISSN: 2574-1241}

DOI: 10.26717.BJSTR.2019.14.002500

Muhammad Torequl Islam. Biomed J Sci \& Tech Res

(c) (i) This work is licensed under Creative

Submission Link: https://biomedres.us/submit-manuscript.php
30. Chatterjee TK (1993) Handbook on laboratory mice and rats.1st ed. (Kolkata, Department of Pharmaceutical Technology, Jadavpur University) pp. 157.

31. Duraipandiyan V, Ayyanar M, Ignacimuhu S (2006) Antimicrobialactivity of some ethnomedicinal plants used by Paliyar tribe from Tamil Nadu, India. BMC Comp Alter Med 6: 35-41.

32. Farnsworth NR, Akerele O, Bingel AS, Djaja D Soejarto, Zhengang Guo (1985) Medicinal plantsin therapy Bull WHO 63(6): 965-981.

33. Moghal MMR, Siddiqui R, M Masud Alam, A F M Shahid-Ud-Daula, Mohammad Shahriar, et al. (2011) The Antimicrobial activity and Brine Shrimp Lethality Bioassay of Leaf extracts of Stephania japonica (Akanadi). Bangladesh J Microbiol 28: 52-56.

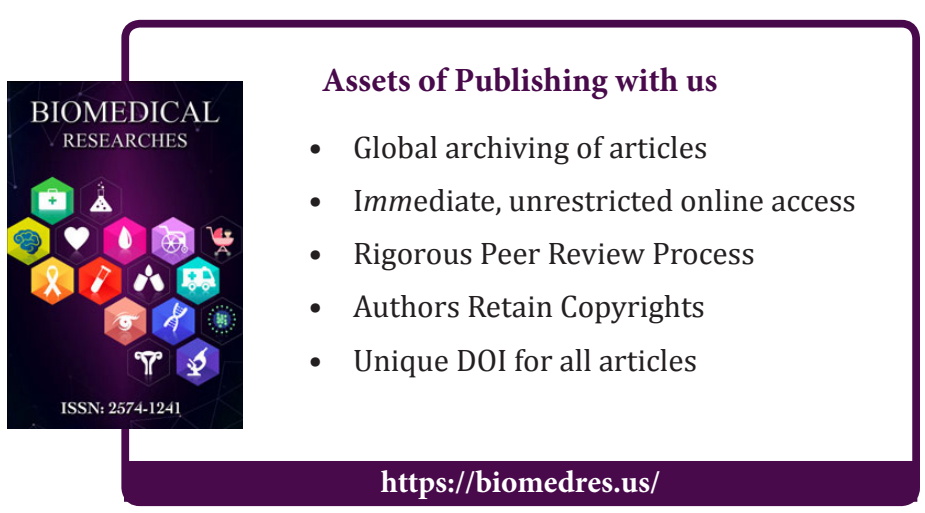

